\title{
Boric Acid as Cost-Effective and Recyclable Catalyst for Trimethylsilyl Protection and Deprotection of Alcohols and Phenols
}

\author{
Amin Rostami, * Jamal Akradi and Firoz Ahmad-Jangi \\ Department of Chemistry, Faculty of Science, University of Kurdistan, Sanandaj, Iran
}

\begin{abstract}
O ácido bórico foi usado neste trabalho como um catalisador "verde", seletivo e reciclável, para a trimetilsililação de álcoois e fenóis usando hexametildissilazano em acetonitrila. A desproteção de trimetilsililéteres para regenerar seus alcoóis e fenóis precursores foi também realizada usando este catalisador em água à temperatura ambiente. As características de destaque desta metodologia são o baixo custo do processo, as condições brandas de acidez, os rendimentos excelentes e a disponibilidade ampla do catalisador.
\end{abstract}

Boric acid has been used as a green, selective and recyclable catalyst for trimethysilylation of alcohols and phenols using hexamethyldisilazane in acetonitrile. Deprotection of trimethylsilyl ethers to their parent alcohols and phenols was also achieved using this catalyst in water at room temperature. The salient features of this methodology are cheap processing, mild acidity conditions, excellent yields of products and easy availability of the catalyst.

Keywords: boric acid, catalyst, hydroxyl groups, hexamethyldisilazane, trimethylsilyl ether

\section{Introduction}

The protection and deprotection of hydroxyl groups by the formation and cleavage of silyl ethers have been extensively used in organic synthesis. ${ }^{1}$ Among the many agents which have been used for the silylation of hydroxyl groups, ${ }^{2}$ hexamethyldisilazane (hmds), a cheap, stable and commercially available reagent, ${ }^{3}$ is selected as one of the best candidates for this purpose. Its handling does not need special precaution, and the work-up is not time-consuming, as the by-product of the reaction is ammonia, which is simple to remove from the reaction medium. However, the major disadvantage and drawback of this reagent is its poor reactivity, which demands hard conditions and long reaction times in many reactions. Hence, a variety of catalysts has been reported for the activation of hmds. ${ }^{4-13}$ Some of these chemicals are neither common nor cost-effective and are therefore difficult to be applied for scale-up operations.

Similar to protection, deprotection of the trimethylsilyl ethers constitutes an important process in the synthetic chemistry of polyfunctional molecules including the total synthesis of natural products. Although several methods have been reported for the deprotection of trimethylsilyl ethers, ${ }^{14-17}$ to the best of our knowledge there are only two reports

*e-mail: a_rostami372@yahoo.com for both protection and deprotection of alcohols and phenols as trimethylsilyl (tms) ethers in the presence of catalyst. ${ }^{18-19}$ Therefore, there is still a demand to develop environmentally acceptable protocols for the trimethylsilylation of hydroxyl compounds and their regeneration in the presence of inexpensive and bench-top catalysts.

Water is the ideal green solvent for many mild catalytic transformations from both economical and environmental perspectives. ${ }^{20}$ Boric acid, in turn, is commercially available, environmental compatible, very cheap, easy to handle and chemically stable. It is a weak acid $\left(\mathrm{pK}_{\mathrm{a}}=9.24\right)$ and can produce $\mathrm{H}^{+}$from its reaction with water or alcohol $\left(\mathrm{B}(\mathrm{OH})_{3}+\mathrm{ROH} \rightarrow \mathrm{B}(\mathrm{OH})_{3}(\mathrm{OR})^{-}+\mathrm{H}^{+}\right)$. Boric acid was recently shown to have a good profile for substituting for conventional acidic catalytic materials. ${ }^{21-26}$ These properties prompted us to select boric acid as the catalyst in the present work.

In our ongoing research program to develop new synthetic methodologies for protection and deprotection of organic functional groups, ${ }^{27-30}$ we conceived that boric acid, which can generate $\mathrm{H}^{+}$in the reaction medium on reaction with alcohol or water, might be a useful catalyst for protection and deprotection of alcohols and phenols as tms ethers.

In this paper we disclose that boric acid can be used as an efficient catalyst for trimethysilylation of a wide range 


\section{$\mathrm{R}-\mathrm{OH} \stackrel{\text { Boric acid (catalyst), hmds, } \mathrm{CH}_{3} \mathrm{CN} \text {, r.t. }}{\text { Boric acid (catalyst), } \mathrm{H}_{2} \mathrm{O} \text {, r.t. }} \mathrm{R}-\mathrm{OSiMe}_{3}$}

Scheme 1.

of alcohols and phenols using hmds in $\mathrm{CH}_{3} \mathrm{CN}$ and their deprotection to the corresponding parent compounds in $\mathrm{H}_{2} \mathrm{O}$ at room temperature (Scheme 1).

\section{Results and Discussion}

In order to optimize the reaction conditions, we first examined the effect of different molar ratios of $\mathrm{ROH} /$ $\mathrm{hmds} /$ catalyst in various solvents. Silylation assays were conducted using a 1:1.5:0.1 mixture of 4-methoxybenzyl alcohol, hmds and boric acid respectively. Acetonitrile gave the best results and produced the expected trimethylsilyl ether in $95 \%$ yield (Table 1).

Table 1. Effect of solvent ( $1 \mathrm{~mL}$ ) on trimethylsilylation of 4-methoxybenzyl alcohol $(1 \mathrm{mmol})$ using hmds $(1.5 \mathrm{mmol})$, catalyzed with boric acid $(0.1 \mathrm{mmol})$ at room temperature

\begin{tabular}{llcc}
\hline Entry & Solvent & Conversion $^{\mathrm{a}}$ / (\%) & Isolated yields / (\%) \\
\hline 1 & Solvent-free & 55 & 49 \\
2 & Water & 50 & 47 \\
3 & Dichloromethane & 35 & 32 \\
4 & Acetonitrile & 95 & 90 \\
5 & Diethyl ether & 50 & 45 \\
6 & Toluene & 85 & 79 \\
7 & $n$-Hexane & 40 & 37 \\
\hline
\end{tabular}

aReaction time in all cases: $1 \mathrm{~h}$.

The effects of the relative amounts of hmds $(0.8-1.5 \mathrm{mmol})$ and boric acid $(0.02-0.1 \mathrm{mmol})$ on the outcome of trimethylsilylation of 4-methoxybenzyl alcohol were also studied (Table 2). It appears that a molar ratio substrate/hmds/boric acid of 1/0.8/0.1 is the suitable choice for this reaction.

Table 2. Effect of hmds and boric acid amounts on silylation of 4-methoxybenzyl alcohol $(1 \mathrm{mmol})$ in $\mathrm{CH}_{3} \mathrm{CN}(1 \mathrm{~mL})$ at room temperature

\begin{tabular}{lccc}
\hline Entry & $\begin{array}{c}\text { Substrate/hmds/ } \\
\text { Boric acid / } \\
\text { Molar ratio }\end{array}$ & Conversion $^{\mathrm{a}}$ / (\%) & Isolated yields / (\%) \\
\hline 1 & $1: 1.5: 0.1$ & 92 & 86 \\
2 & $1: 0.8: 0.1$ & 90 & 85 \\
3 & $1: 0.8: 0.05$ & 70 & 66 \\
4 & $1: 0.8: 0.02$ & 45 & 42 \\
\hline
\end{tabular}

${ }^{a}$ Reaction time in all cases: $1 \mathrm{~h}$.
Using the best conditions established above (1:0.8:0.1 molar ratio for substrate/hmds/boric acid, in acetonitrile at room temperature), a series of alcohols has been subsequently experimented. As shown in Table 3, primary benzylic alcohols (including electron releasing or withdrawing groups and acid sensitive groups) and aliphatic alcohols were silylated with good to high yields (entries 1-8). The primary benzylic alcohols are more reactive than primary aliphatic alcohols. The benzylic, cyclic and linear secondary alcohols are successfully protected using this method by increasing the molar ratio of hmds and catalyst (entries 9-12). This method was also found to be useful for trimethylsilylation of allylic alcohols (entry 13) and diols (entries 14 and 15). We were then interested in whether the same catalyst could be employed for trimethysilylation of phenolic compounds. Under the same conditions as above, most of the tested phenols (Table 3, entries 16-18) were smoothly converted into the corresponding tms ethers in good yields. No elimination and rearrangement by-products were observed at all.

Notably, tertiary alcohol, phenols possessing withdrawing groups, amines and thiols did not react using this method (Table 3, entries 19-22).

As shown in Table 3, the required amounts of hmds and catalyst depend on the nature of the alcohol used as substrate. The importance of the selectivity issue in synthetic organic chemistry led us to carry out competitive reactions in order to evaluate the chemoselectivity of the protocol. In a binary mixture of 3,4-(methylenedioxy)benzyl alcohol (as a model for primary alcohol) and 1-phenylethanol (as a model for secondary alcohol), the molar ratio of primary silyl ether to secondary silyl ether is $95 / 5 \%$ (Scheme 2).

In view of considering the capability of boric acid to produce $\mathrm{H}^{+}$in water, we investigated the possibility of deprotection of trimethylsilyl ethers using boric acid as a catalyst in water. We successfully converted various tms ethers to the parent hydroxyl compounds in the presence of catalytic amount of boric acid in water at room temperature. The results are summarized in Table 4.

The recovery and reusability of the insoluble catalyst was investigated in the silylation of 3,4-(methylenedioxy)benzyl alcohol $(1 \mathrm{mmol})$ with hmds $(0.8 \mathrm{mmol})$. After completion of the reaction, the solvent was evaporated and $n$-hexane $(20 \mathrm{~mL})$ was added to the residual mixture and then the insoluble catalyst was removed by filtration. The recovered catalyst was used in the next run. The results showed that the 
Table 3. Trimethylsilylation of alcohols and phenols using hmds catalyzed with boric acid in $\mathrm{CH}_{3} \mathrm{CN}(1 \mathrm{~mL})$ at room temperature

\begin{tabular}{|c|c|c|c|c|c|}
\hline Entry & Substrate & $\begin{array}{c}\text { Substrate/hmds/Boric } \\
\text { acid / mmol }\end{array}$ & time $/ \mathrm{h}$ & Yields / $(\%)^{\mathrm{a}}$ & $\operatorname{Ref}^{b}$ \\
\hline 1 & 4- $\mathrm{MeO}-\mathrm{C}_{6} \mathrm{H}_{4} \mathrm{CH}_{2} \mathrm{OH}$ & 1:0.8:0.1 & 1.6 & 85 & 10 \\
\hline 2 & 4- $\mathrm{Cl}-\mathrm{C}_{6} \mathrm{H}_{4} \mathrm{CH}_{2} \mathrm{OH}$ & 1:0.8:0.1 & 1.5 & 90 & 9 \\
\hline 3 & $2,4-(\mathrm{Cl})_{2} \mathrm{C}_{6} \mathrm{H}_{3} \mathrm{CH}_{2} \mathrm{OH}$ & 1:0.8:0.1 & 1.1 & 96 & 6 \\
\hline 4 & $4-\mathrm{NO}_{2}-\mathrm{C}_{6} \mathrm{H}_{4} \mathrm{CH}_{2} \mathrm{OH}$ & 1:0.8:0.2 & 5 & 96 & 5 \\
\hline 5 & & 1:0.8:0.1 & 0.7 & 85 & 2 \\
\hline 6 & & 1:0.8:0.1 & 1 & 80 & 7 \\
\hline 7 & $\mathrm{PhCH}_{2} \mathrm{CH}_{2} \mathrm{OH}$ & 1:1.6:0.2 & 0.5 & 80 & 10 \\
\hline 8 & $\mathrm{CH}_{3}\left(\mathrm{CH}_{2}\right)_{6} \mathrm{CH}_{2} \mathrm{OH}$ & 1:1.6:0.2 & 2.1 & 80 & 10 \\
\hline 9 & $\mathrm{PhCH}(\mathrm{OH}) \mathrm{CH}_{3}$ & 1:1.6:0.2 & 1 & 95 & 10 \\
\hline 10 & $\mathrm{PhCH}(\mathrm{OH}) \mathrm{Ph}$ & $1: 0.8: 0.1$ & 3 & 85 & 10 \\
\hline 11 & $\mathrm{H}_{2}(\mathrm{OH}) \mathrm{CH}_{3}$ & $1: 1.6: 0.2$ & 2.1 & 92 & 18 \\
\hline 12 & & 1:1.6:0.2 & 1.1 & 95 & 6 \\
\hline 13 & ${ }_{2} \mathrm{OH}$ & 1:1.6:0.2 & 20 & 95 & 6 \\
\hline 14 & $\mathrm{DH}$ & 1:1.6:0.2 & 2 & 95 & 11 \\
\hline 15 & & $1: 1.6: 0.2$ & 2 & 97 & 6 \\
\hline 16 & 4- $(\mathrm{MeO}) \mathrm{C}_{6} \mathrm{H}_{4} \mathrm{OH}$ & 1:0.8:0.1 & 3 & 95 & 4 \\
\hline 17 & & 1:0.8:0.1 & 2.7 & 92 & 11 \\
\hline 18 & & 1:0.8:0.1 & 6 & 90 & 18 \\
\hline 19 & $-\mathrm{CH}_{3}$ & $1: 20: 0.5$ & 30 & - & \\
\hline 20 & $4-\mathrm{NO}_{2} \mathrm{C}_{6} \mathrm{H}_{4} \mathrm{OH}$ & $1: 1.6: 0.2$ & 30 & - & \\
\hline 21 & $\mathrm{C}_{6} \mathrm{H}_{5} \mathrm{NH}_{2}$ & $1: 1.6: 0.2$ & 30 & - & \\
\hline 22 & $\mathrm{C}_{6} \mathrm{H}_{5} \mathrm{SH}$ & $1: 1.6: 0.2$ & 30 & - & \\
\hline
\end{tabular}

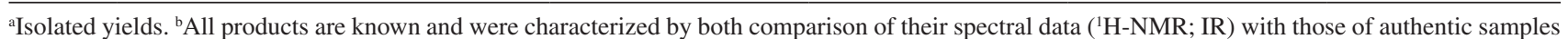
and also by the conversion of the products to their corresponding starting materials. 
<smiles>CC(O)c1ccccc1</smiles><smiles>COCc1cccc2c1OCO2</smiles>

Scheme 2.

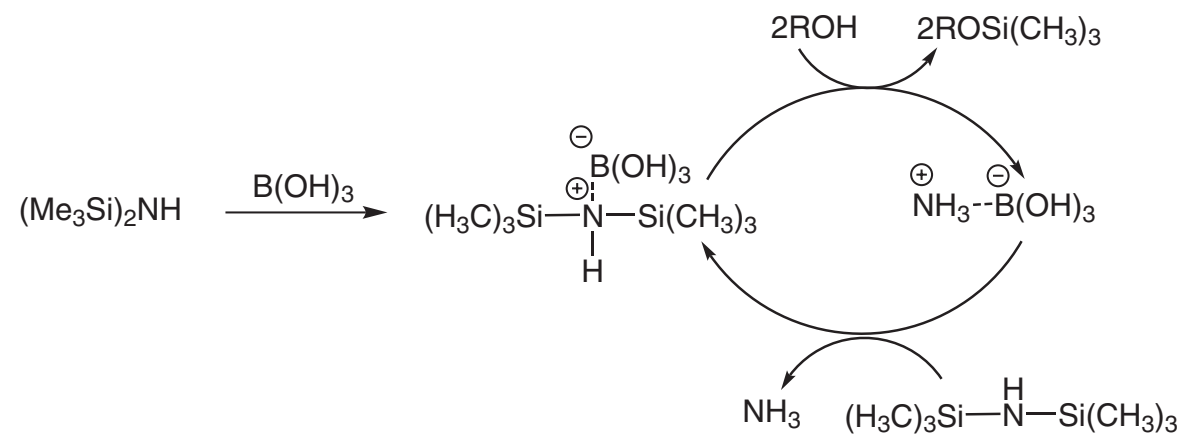

Scheme 3. Proposed mechanism for the trimethylsilylation of alcohols and phenols.

catalyst can be reused several times (three consecutive runs were checked) without significant loss of activity. The yields of recovered catalyst were $83 \%, 80 \%$ and $81 \%$ respectively.

On the basis of the previously reported mechanisms for the catalytic application of boric acid in organic synthesis, ${ }^{21-24}$ one idea for trimethysilylation of hydroxyl compounds is that boric acid acts as a Lewis acid, which may polarize the $\mathrm{Si}-\mathrm{N}$ bond in hmds by coordinating with the nitrogen (Scheme 3 ). However, at this time the precise role of boric acid is not clear and should be further studied in detail.

\section{Conclusions}

In summary, we have demonstrated the potential of boric acid as a cost-effective, recyclable and environmentally benign catalyst for the protection of a variety of alcohols and phenols as tms ethers using hmds, and their deprotection under very mild conditions. The product yields are excellent and the work-up is easy and clean.

\section{Experimental}

\section{General}

Chemicals including starting materials, solvents and boric acid (CAS: 10043-35-3) were obtained from Merck chemical company and used without purification. FT-IR spectra were recorded on a Perkin Elmer RXI spectrometer. NMR spectra were recorded on a Bruker Avance DPX $250 \mathrm{MHz}$ instrument. Chemical shifts $(\delta)$ are given in ppm and coupling constants $(J)$ in Hz. Deuterated solvents were used as lock and reference $\left[{ }^{1} \mathrm{H}\right.$ NMR relative to the hydrogen resonance resulting from incomplete deuteration of the $\mathrm{CDCl}_{3}(\delta 7.25) ;{ }^{13} \mathrm{C} \mathrm{NMR}$ relative to the carbon of the $\left.\mathrm{CDCl}_{3}(\delta 77.0)\right]$. The products were purified by column chromatography. Thin layer chromatography (TLC) was performed on SIL G/UV 254 plates.

General procedure for trimethlysilylation of alcohols and phenols using hmds in the presence of boric acid in acetonitrile

Alcohols or phenols ( $1 \mathrm{mmol})$ were added to a mixture of hmds (0.13 g, $0.8 \mathrm{mmol})$ and boric acid $(0.0062 \mathrm{~g}$, $0.1 \mathrm{mmol})$ in $\mathrm{CH}_{3} \mathrm{CN}(1 \mathrm{~mL})$, and then the mixture was stirred at room temperature for the specified time (Table 3 ). The progress was monitored by TLC. After completion of the reaction, the solvent was evaporated, and $20 \mathrm{~mL}$ of $n$-hexane (or diethyl ether for low boiling point tms ethers) was added to the residual mixture. Insoluble catalyst was removed by filtration. $10 \%$ aqueous $\mathrm{NaHCO}_{3}(10 \mathrm{~mL})$ was added to destroy the extra amount of hmds, and then the organic layer was separated and dried over anhydrous $\mathrm{Na}_{2} \mathrm{SO}_{4}$. Evaporation of the $n$-hexane under reduced pressure 
Table 4. Deprotection of trimethylsilyl ethers $(1 \mathrm{mmol})$ in the presence of catalytic amount of boric acid in water $(2 \mathrm{~mL})$ at room temperature

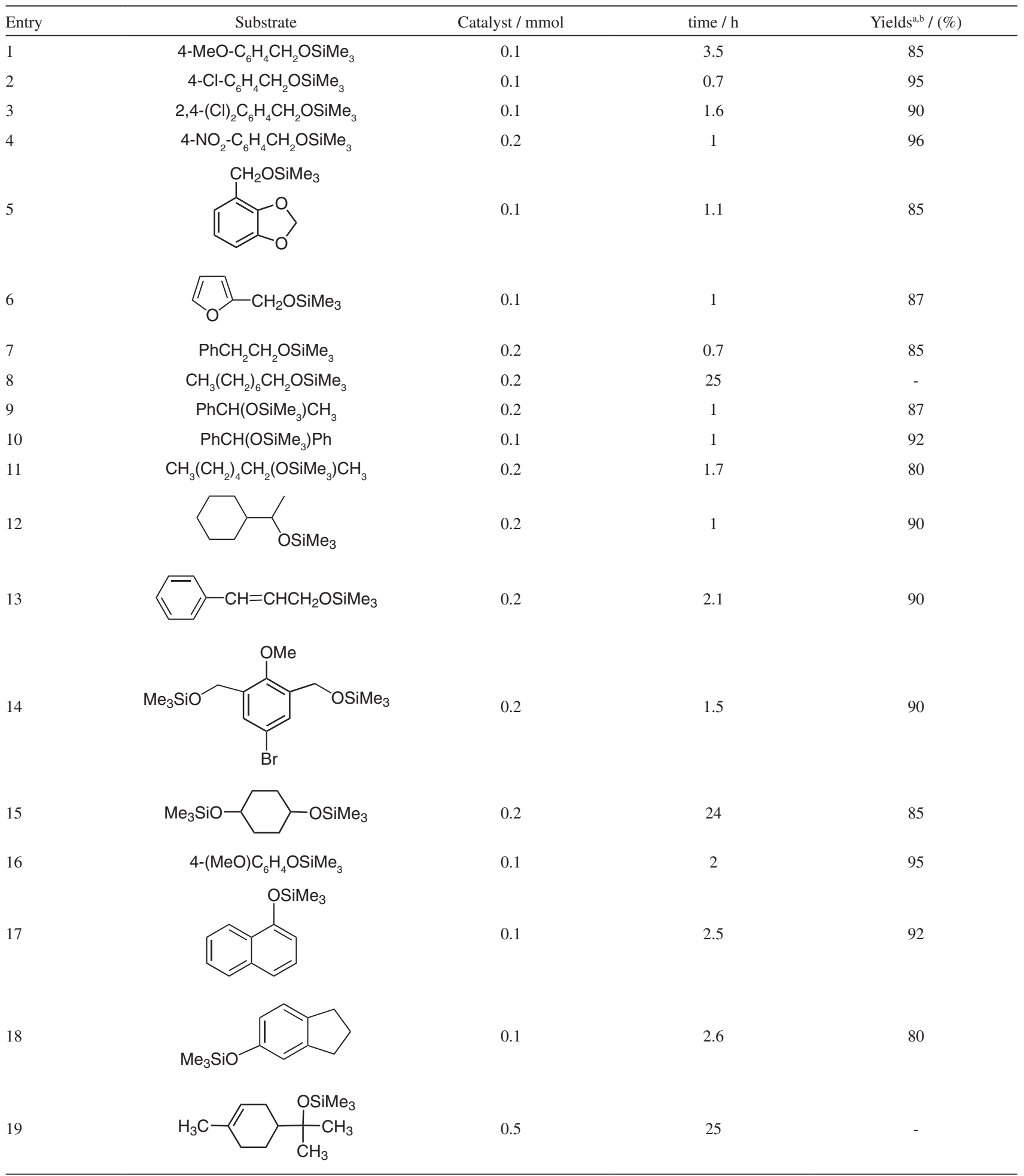

${ }^{\mathrm{a} A l l}$ products were characterized by comparison of their spectral data $\left({ }^{1} \mathrm{H}-\mathrm{NMR}\right.$; IR) with those of authentic samples. ${ }^{\mathrm{b}}$ Isolated yields.

gave the pure silyl ether without additional purification in the most case. When necessary, further purification was performed by short-column chromatography on silica gel with ethyl acetate/ $n$-hexane (1/10) as eluent.
Trimethyl(4-methoxybenzyloxy)silane (Table 3, entry 1)

Eluent: $n$-hexane/ethyl acetate (10:1); colorless oil $(0.179 \mathrm{~g}, 85 \%)$; IR (film) $v_{\max } / \mathrm{cm}^{-1}: 2955 \mathrm{vs}, 2854 \mathrm{vs}, 1615 \mathrm{~m}$, $1587 \mathrm{w}, 1514 \mathrm{vs}, 1464 \mathrm{~s}, 1377 \mathrm{~m}, 1302 \mathrm{~m}, 1250 \mathrm{vs}, 1172 \mathrm{~m}$, 
1087s, 1041m, 876vs, 842vs, 747m. ${ }^{1} \mathrm{H} \mathrm{NMR}\left(\mathrm{CDCl}_{3}\right.$, $250 \mathrm{MHz}) \delta 0.21\left(\mathrm{~s}, 9 \mathrm{H},\left(\mathrm{CH}_{3}\right)_{3} \mathrm{Si}\right), 3.81\left(\mathrm{~s}, 3 \mathrm{H}, \mathrm{CH}_{3} \mathrm{O}\right)$, 4.66 (s, 2H, $\left.\mathrm{PhCH}_{2}\right), 6.95$ (d, J 8.2 Hz, 2H, PhH), 7.32 (d, $J 8.2 \mathrm{~Hz}, 2 \mathrm{H}, \mathrm{PhH}) .{ }^{13} \mathrm{C} \mathrm{NMR}\left(\mathrm{CDCl}_{3}, 62.9 \mathrm{MHz}\right) \delta-0.36$, $55.18,64.38,113.70,128.11,133.11,158.86$.

\section{General procedure for deprotection of trimethylsilyl ethers catalyzed by boric acid}

Boric acid $(0.0062 \mathrm{~g}, 0.1 \mathrm{mmol})$ was added to a mixture of tms ethers $(1 \mathrm{mmol})$ in $\mathrm{H}_{2} \mathrm{O}(2 \mathrm{~mL})$ and then the mixture was stirred at room temperature for the specified time (see Table 4). The progress of the reaction was monitored by TLC. On completion of the reaction, the product was extracted with diethyl ether $(3 \times 10 \mathrm{~mL})$ and then the organic layer was dried over anhydrous $\mathrm{Na}_{2} \mathrm{SO}_{4}$. Evaporation of the solvent under reduced pressure gave the pure alcohols or phenols without further purification.

\section{Supplementary Information}

Supplementary information (FTIR and NMR spectra of trimethyl(4-methoxybenzyloxy)silane, Figures S1-S3) is available free of charge at http://jbcs.sbq.org.br, as PDF file.

\section{Acknowledgments}

We are thankful to the University of Kurdistan Research Councils for partial support of this work.

\section{References}

1. Greene, T. W.; Wuts, P. G. M.; Protective Groups in Organic Synthesis, $3^{\text {rd }}$ ed., John Wiley: New York, 1999.

2. Deveau, A. M.; Macdonald, T. L.; Tetrahedron Lett. 2004, 45, 803.

3. Corey, E. J.; Venkateswarlu, A.; J. Am. Chem. Soc. 1972, 94, 6190.

4. Zhang, Z. H.; Li, T. S.; Yang, F.; Fu, C. G.; Synth. Commun. 1998, 28, 3105 .

5. Curini, M.; Epifano, F.; Marcotullio, M. C.; Rosati, O.; Costantino, U.; Synth. Commun. 1999, 29, 541.

6. Karimi, B.; Golshani, B.; J. Org. Chem. 2000, 65, 7228.

7. Azizi, N.; Saidi, M. R.; Organometallics 2004, 23, 1457.

8. Akhlaghinia, B.; Tavakoli, S.; Synthesis 2005, 1775.
9. Firouzabadi, H.; Iranpoor, N.; Sobhani, S.; Gassamipour, S.; Synthesis 2005, 595.

10. Shaterian, H. R.; Shahrekipoor, F.; Ghashang, M.; J. Mol. Catal. A: Chem. 2007, 272, 142.

11. Khazaei, A.; Zolfigol, M. A.; Tanbakouchian, Z.; Shiri, M.; Niknam, K.; Saien, J.; Catal. Commun. 2007, 8, 917.

12. Moghadam, M.; Tangestaninejad, S.; Mirkhani, V.; Mohammadpoor-Baltork, I.; Chahardahcheric, S.; Tavakoli, Z.; J. Organomet. Chem. 2008, 693, 2041.

13. Shirini, F.; Zolfigol, M. A.; Abedini, M.; Monatsh. Chem. 2009, 140, 61 .

14. Yu, Z.; Vercade, J. G.; J. Org. Chem. 2000, 65, 2065.

15. Wu, Y. J.; Huang, H.; Shen, X.; Hu, Q.; Tangn, C- J.; Li, L.; Org. Lett. 2002, 4, 2141.

16. Levin, J. I.; Du, M. T.; Park. K.; Synth. Commun. 2004, 34, 2773.

17. Crouch, R. D.; Williams, A.; Synth. Commun. 2006, 36, 959.

18. Khazaei, A.; Rostami, A.; Raiatzadeh, A.; Mahboubifar, M.; Can. J. Chem. 2007, 85, 336.

19. Lakouraj, M. M.; Akbari, A.; Indian J. Chem., Sect. B: Org. Chem. Incl. Med. Chem. 2003, 42, 1165.

20. Kobayashi, S.; Manabe, K.; Acc. Chem. Res. 2002, 35, 209.

21. Tu, S.; Fang, F.; Miao, C.; Jiang, H.; Feng, Y.; Shi, D.; Wang, X.; Tetrahedron Lett. 2003, 44, 6153.

22. Maki, T.; Ishihara, K.; Yamamoto, H.; Org. Lett. 2005, 7, 5047.

23. Chaudhuri, M. K.; Hussain, S.; J. Mol. Catal. A: Chem. 2007, 269, 214.

24. Kondaiah, G. C. M.; Reddy, L. A.; Babu, K. S.; Gurav, V. M.; Huge, K. G.; Bandichhor, R.; Reddy, P. P.; Bhattacharya, A.; Anand, R. V.; Tetrahedron Lett. 2008, 49, 106.

25. Barajas, J. G. H.; Méndez, L. Y. V.; Kouznetsov, V. V.; Stashenko, E. E.; Synthesis 2008, 377.

26. Mukhopadhyay, C.; Tapaswi, P. K.; Butcher, R. J.; Aust. J. Chem. 2009, 62, 140.

27. Khazaei, A.; Rostami, A.; Tanbakouchian, Z.; Zinati, Z.; J. Braz. Chem. Soc. 2006, 17, 206.

28. Khazaei, A.; Rostami, A.; Mahboubifar, M.; Catal. Commun. 2007, 8, 383.

29. Rostami, A.; Khazaei, A.; Mahboubifar, M.; Rahmati, S.; Org. Prep. Proced. Int. 2008, 40, 303.

30. Rostami, A.; Rahmati, S.; Khazaei, A.; Monatsh. Chem. 2009, 140,663 


\section{Boric Acid as Cost-Effective and Recyclable Catalyst for Trimethylsilyl Protection and Deprotection of Alcohols and Phenols}

\section{Amin Rostami, * Jamal Akradi and Firoz Ahmad-Jangi}

Department of Chemistry, Faculty of Science, University of Kurdistan, Sanandaj, Iran

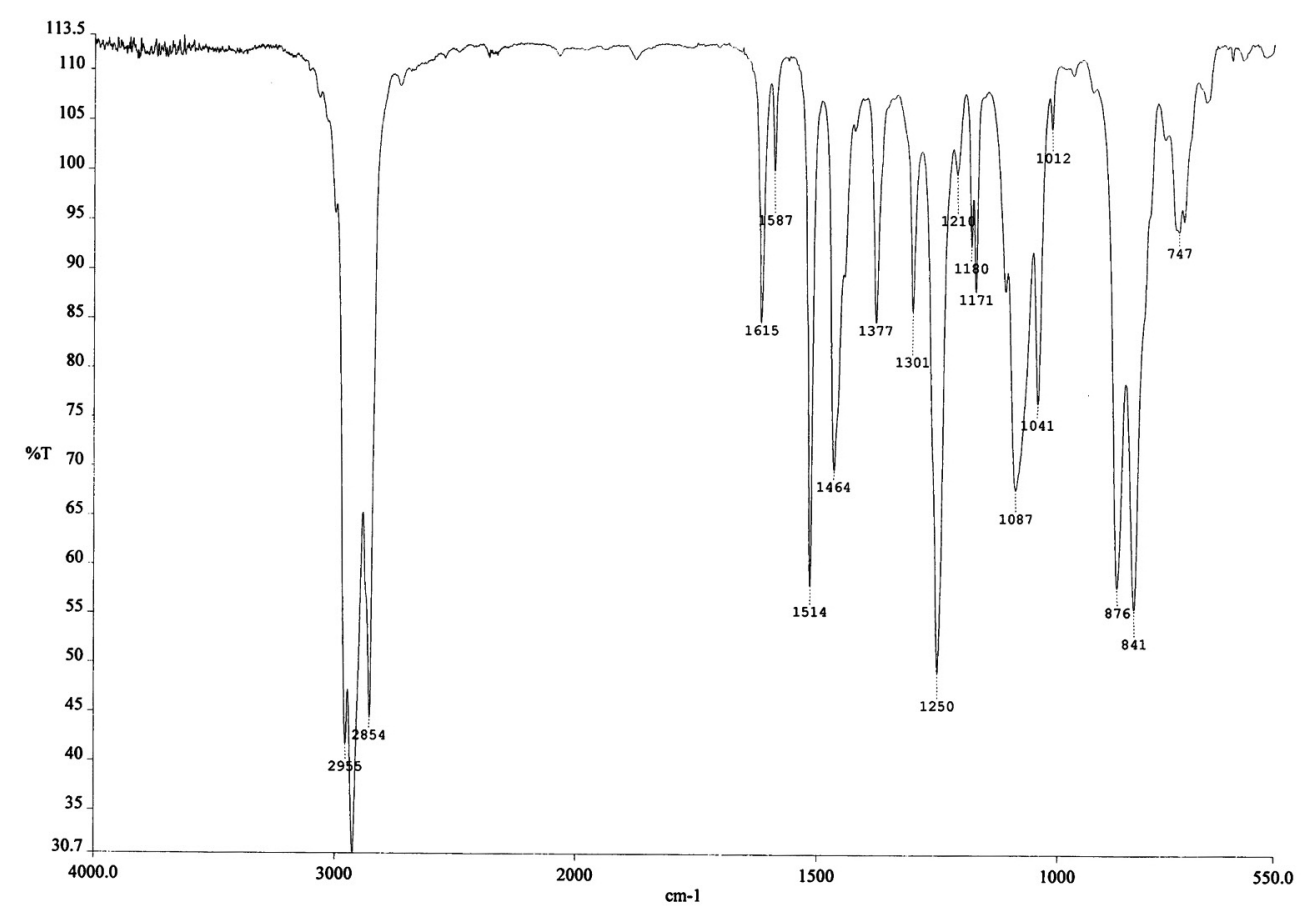

Figure S1. FTIR spectrum of trimethyl(4-methoxybenzyloxy)silane. 


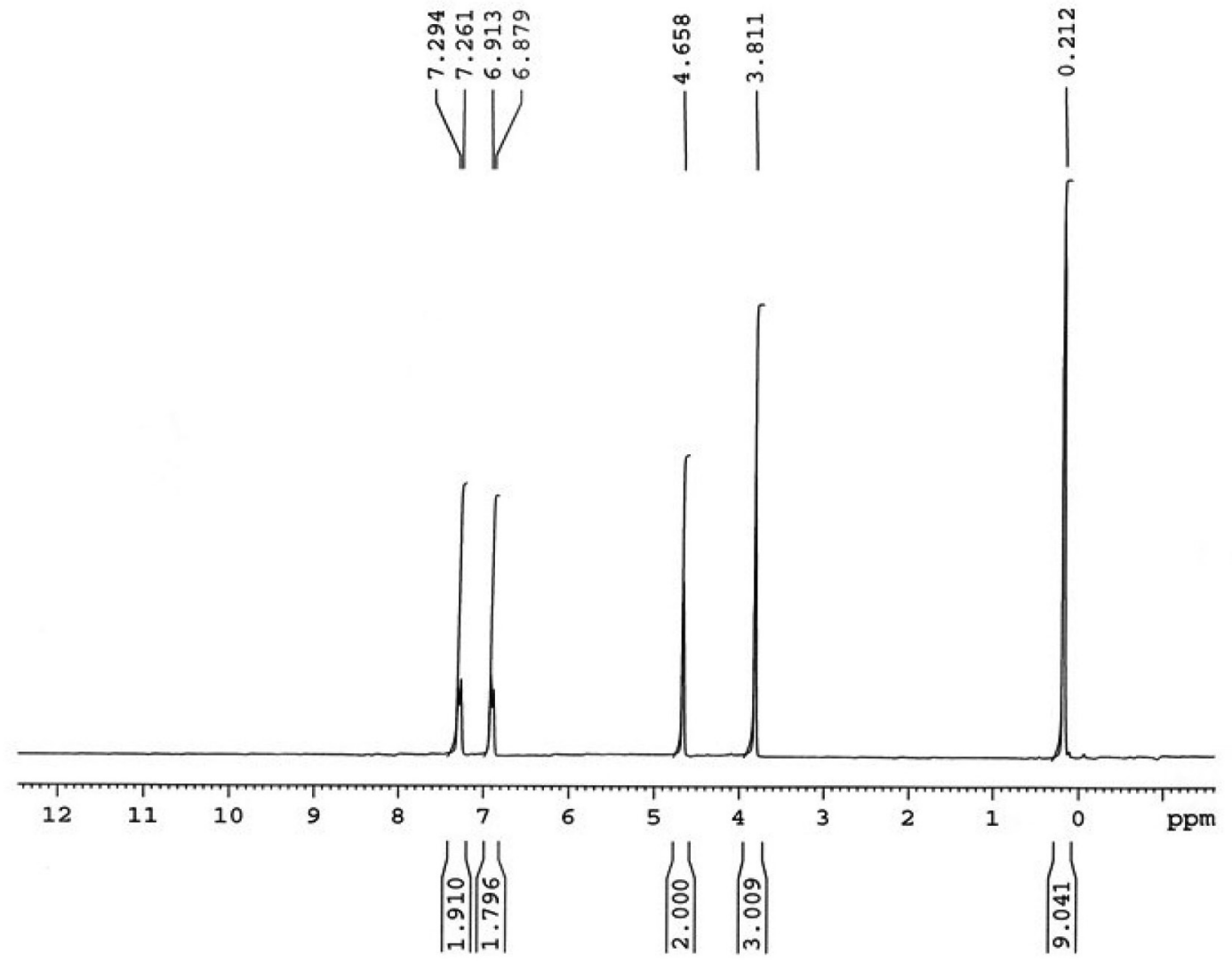

Figure S2. ${ }^{1} \mathrm{H}$ NMR spectrum ( $250 \mathrm{MHz}, \mathrm{CDCl}_{3}$ ) of trimethyl(4-methoxybenzyloxy)silane.
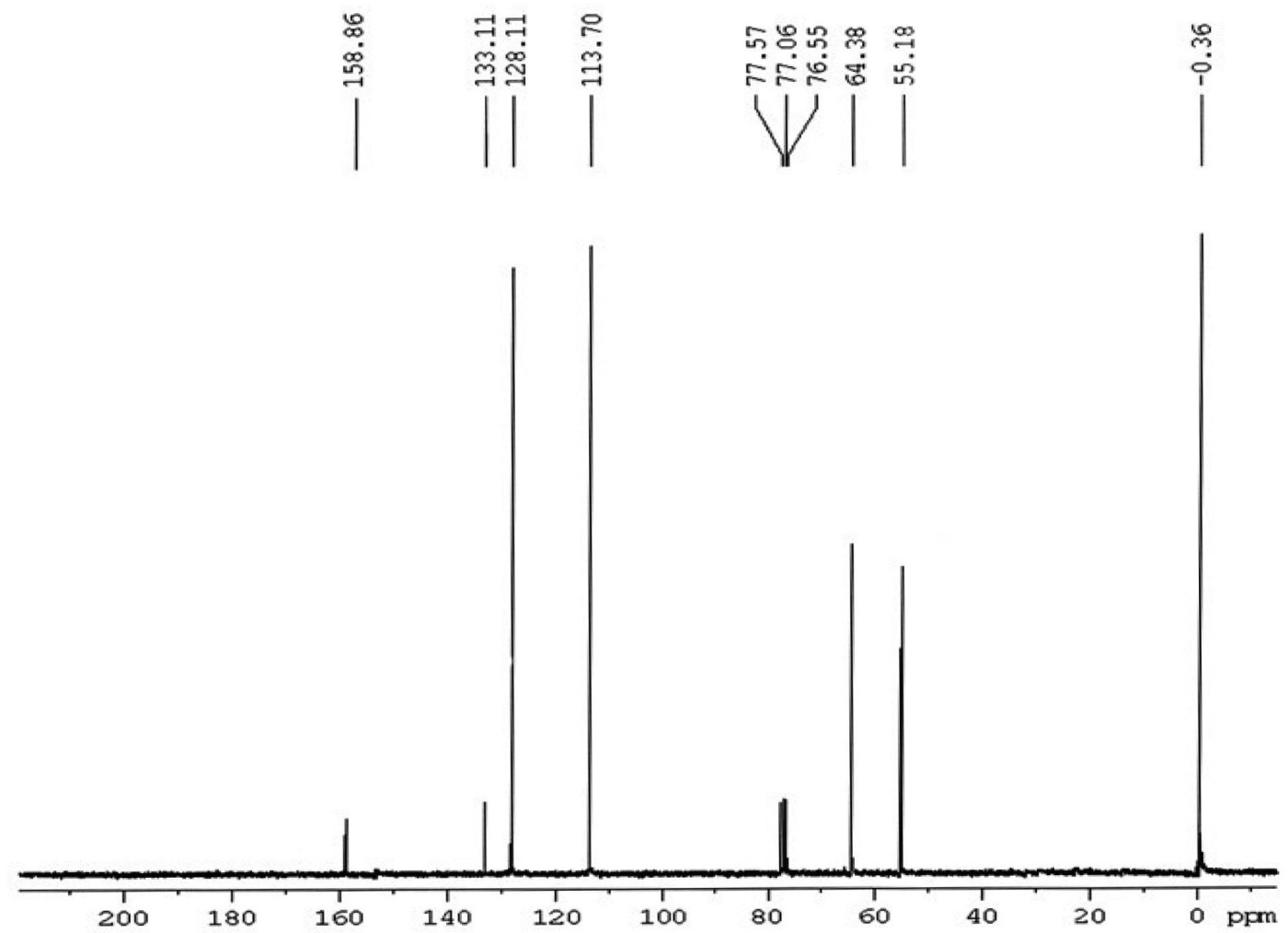

Figure S3. ${ }^{13} \mathrm{C}\left\{{ }^{1} \mathrm{H}\right\}$ NMR spectrum $\left(\mathrm{CDCl}_{3}, 62.9 \mathrm{MHz}\right)$ of trimethyl(4-methoxybenzyloxy)silane. 